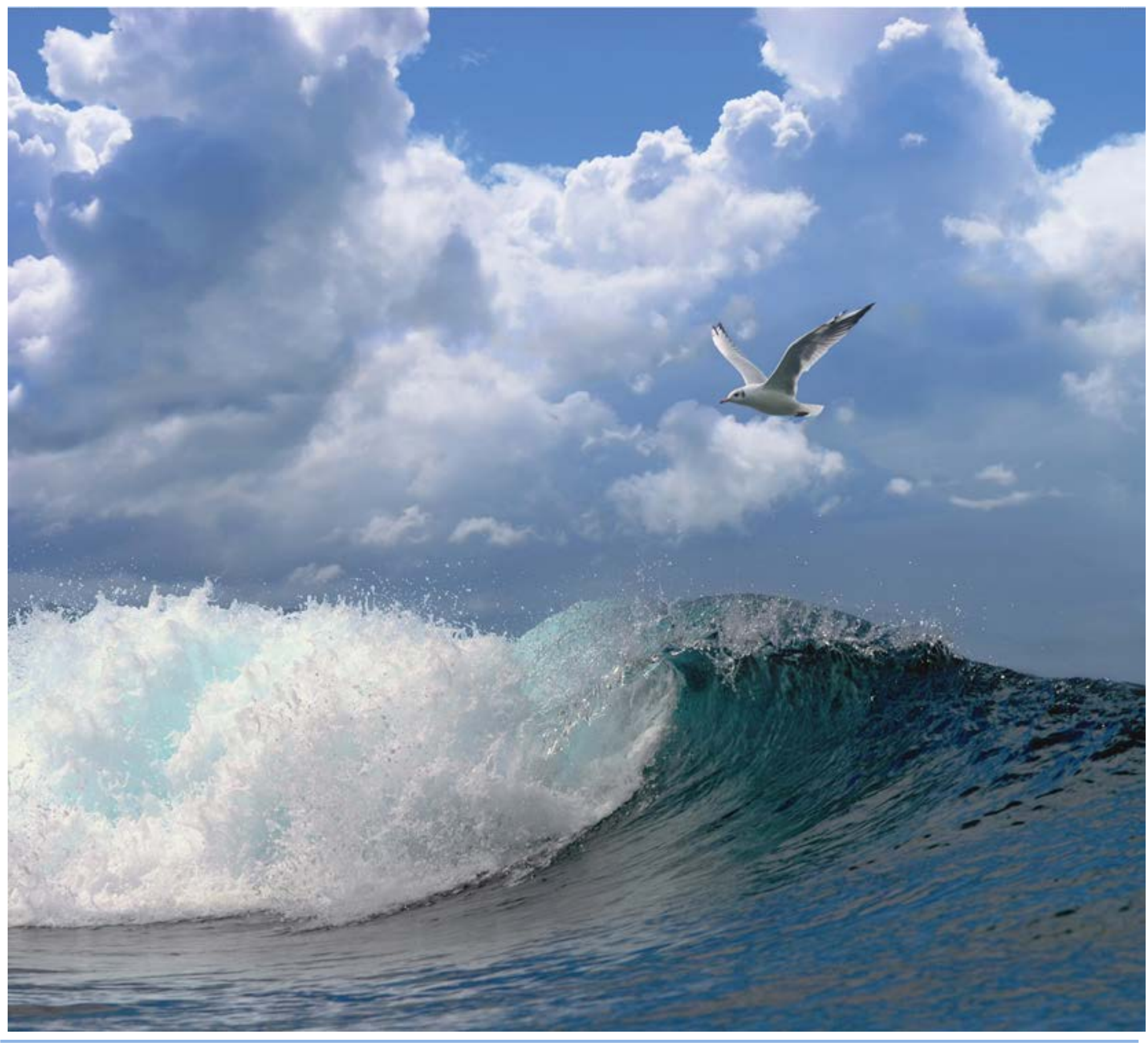

Feasibility study on culturing Pacific oysters in the Wadden Sea of Schleswig-Holstein 


\section{Feasibility study on culturing Pacific oysters in the Wadden Sea of Schleswig-Holstein}

Part I. An inventory of the possibilities for resource provisioning for an oyster farm on Sylt

Author(s): J Jacob Capelle, Pauline Kamermans

Publication date: 21 December 2017 
Capelle, J.J. and Kamermans, P.,2017. Feasibility study on culturing Pacific oysters in the Wadden Sea of Schleswig-Holstein; Part I. An inventory of the possibilities for resource provisioning for an oyster farm on Sylt. Wageningen, Wageningen Marine Research (University \& Research centre), Wageningen Marine Research report C113/17. 21 pp.

\section{Keywords: Magallana gigas, resource provisioning, hatchery, nursery, spat collection, quarantine}

Client: $\quad$ BioConsult SH GmbH \& Co. KG

Schobüller Str. 36

D-25813 Husum

Germany

This report can be downloaded for free from https://doi.org/10.18174/430123

Wageningen Marine Research provides no printed copies of reports

Wageningen Marine Research is ISO 9001:2008 certified.

(C) 2016 Wageningen Marine Research Wageningen UR

Wageningen Marine Research The Management of Wageningen Marine Research is not responsible for resulting institute of Stichting Wageningen damage, as well as for damage resulting from the application of results or Research is registered in the Dutch research obtained by Wageningen Marine Research, its clients or any claims traderecord nr. 09098104 BTW nr. NL 806511618 related to the application of information found within its research. This report has been made on the request of the client and is wholly the client's property. This report may not be reproduced and/or published partially or in its entirety without the express written consent of the client. 


\section{Contents}

$\begin{array}{llr}1 & \text { Introduction } & 5\end{array}$

$\begin{array}{lll}2 & \text { Hatchery production } & 7\end{array}$

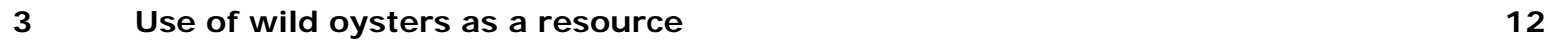

$4 \quad$ Use of spat collectors $\quad 13$

$5 \quad$ Use of a technically safe quarantine for import oysters $\quad 14$

$6 \quad$ Conclusions and recommendations $r$

$\begin{array}{lr}\text { Quality Assurance } & 18\end{array}$

$\begin{array}{lr}\text { References } & 19\end{array}$

$\begin{array}{lr}\text { J ustification } & 20\end{array}$ 


\section{Summary}

This report contains an inventory of the possibilities for resource provisioning for an off-bottom oyster farm on Sylt, Germany. This inventory is based on available literature information and the following possibilities are reviewed:

1. Hatchery production

a) Setup a hatchery, with and without a nursery

b) Use oyster parents from Sylt for breeding in a commercial existing hatchery

c) Import of oyster spat or seed from a commercial hatchery abroad

2. Use of wild oysters as a resource

3. Use of spat collectors

4. Use of a technically safe quarantine for import oysters

Important aspects considered were: risks for the environment, costs, reliability and quality of the resource.

Hatchery production has the advantage that it has a reliable production that can be planned in advance, with a high quality seed as product. However, setting up a hatchery is expensive and when a commercial hatchery abroad is used, oysters from an outdoor nursery might pose an environmental risk. It can also be considered to buy the seed from a hatchery abroad and maintain a nursery on site. When oyster parents from Sylt are used (in a hatchery abroad or on site) it will be ensured that the oysters are adapted to local environmental conditions.

Use of hand-picked or fished oysters from the area has the advantage that oysters are adapted to local conditions, pose no environmental risk. However, quality of wild oysters is generally low, quantity and quality of the resource is unreliable and off-bottom culture should add extra value to increase the selling price.

Spat collectors pose no environmental risk, are cost effective and reliable. Only, the quality of the seed (in terms of shell shape) is generally lower than seed from the hatchery.

Technical safe quarantine is an illusion, as no quarantine is $100 \%$ safe. Risks can be calculated, but this is not in the scope of this study.

Based on the inventory, we propose to carry out a technical analysis for i.) setting up a hatchery on Sylt, ii.) using an existing hatchery abroad with nursery and iii.) using spat collectors).

A full technical description of the methods, techniques and infrastructure needed will be provided in the second part of the feasibility study and will be reported separately. 


\section{$1 \quad$ Introduction}

Wageningen Marine Research was asked to perform part of a feasibility study on the basis of a review existing data, literature and expertise on resource provisioning for an existing oyster farm in Sylt. The aim of the study is to analyse the feasibility of running a local hatchery or to define a method for importing oyster spat to the cultures on Sylt while excluding risks to import alien species or diseases into the area. There are currently no hatcheries in this area and oyster production is dependent on the import of oysters for resource provisioning. When oysters or oyster spat are imported for grow-out from other regions, problems may occur with the introduction of exotic species or diseases (Wolff \& Reise, 2002 ; Verlaque et al., 2007, Table 1). With respect to alien species and diseases a recent court ruling has excluded any direct imports from other areas of the Wadden Sea without sufficient precautionary measures.

The feasibility study consists of two parts. The first part is an inventory of the possibilities for resource provisioning for an oyster farm in List on Sylt. This inventory will be based on available literature information and the following possibilities will be reviewed:

1. Hatchery production

d) the setup a hatchery, with and without a nursery

e) use oyster parents from Sylt for breeding in a commercial existing hatchery/nursery until spat or seed

f) the import of oyster spat or seed from a commercial hatchery abroad

2. The use of wild oysters as a resource

3. Use of spat collectors

4. Use of a technically safe quarantine for import oysters

Second part will report for the most promising possibilities a technical analysis taking into account the conditions at the culture site in Sylt including:

1. Inventory of environmental boundary conditions of the site needed for the technical analysis

2. a full technical description of the methods, techniques and infrastructure needed

3. successes of methods to deal with import risks

This report presents the results first part of the feasibility study: An inventory of the possibilities for resource provisioning for an oyster farm on Sylt 
Table 1. Guidelines to reduce the unintentional introductions by aquaculture. From Verlague et al., 2007.

- Awareness of farmers concerning the risks associated with uncontrolled importation has to be increased.

- Aquaculture should be based on native, local stock whenever possible. Imports and transfers of stock should be minimized, thoroughly inspected, and quarantined for an appropriate observation period.

- Special attention would have to be paid during aquaculture trials with new exotic species (even with livestock from hatcheries).

- Non-native livestock for introduction has to be produced in hatcheries.

- Live products destined for consumption, processing, and aquarium or display should not be placed into the natural environment.

- In the case of livestock transfers (including interregional ones), decontamination processes and/or quarantine as proposed by the ICES (2005) have to be followed.

- Efficient treatment (e.g. hot-seawater for oysters) to avoid introduction or secondary dispersal of exotic or native species would have to be carried out prior to each transfer that is to say after the period of re-immersion preceding the transfer and would have been repeated on arrival. 


\section{Hatchery production}

I mporting seed from abroad for an oyster farm on Sylt can provide risks. The main risk is hitch-hiker species. These species attach to oyster shells in the waters where the oysters grow. When the species are not present in the area where the oysters are transported to we call them non-native. Some species can reproduce and disperse rapidly in the new area and become a nuisance. A method to deal with import risks is hatchery production of oyster seed. Oysters are then produced under controlled conditions in filtered seawater which minimises transfer of organisms other than oysters. However, the use of seed from sources other than the local field population can, in theory, have an effect on the local food availability for shellfish. By adding extra shellfish more food is consumed than was the case before introduction, when the ecosystem was in an equilibrium. Another risk of using seed from a hatchery concerns the genetic composition of the natural population. Generally, hatchery seed is produced with a smaller number of parents than production in the field population. This can cause reduced genetic diversity. Genetic diversity ensures adaptive capacity of the population. The effect of introducing hatchery seed on the natural population depends on the relative amount of hatchery oysters compared to the size of the natural population.

Hatcheries are becoming an essential and growing part of the shellfish industry offering the potential to produce seed on a year-round basis ensuring a stable supply of seed to the production sector. Further, hatcheries can contribute to the restocking of depleted wild stocks following over-harvesting or provide seed when natural spatfall is limited.

In nature, oysters reproduce by releasing eggs and sperm in the water (spawning) where fertilisation takes place and larvae develop. The larvae spend around 3 weeks (Troost, 2009) in the water before they are ready to settle onto a hard substrate. These newly settled larvae are called spat. Spat grows into seed which is the size farmers use in their grow-out facilities. In a hatchery, seed is produced in two steps: larvae and spat are produced indoors, grow-out up to seed size generally takes place in an outdoor nursery. Depending on the grow-out system, spat can also be directly transferred to the grow-out site.

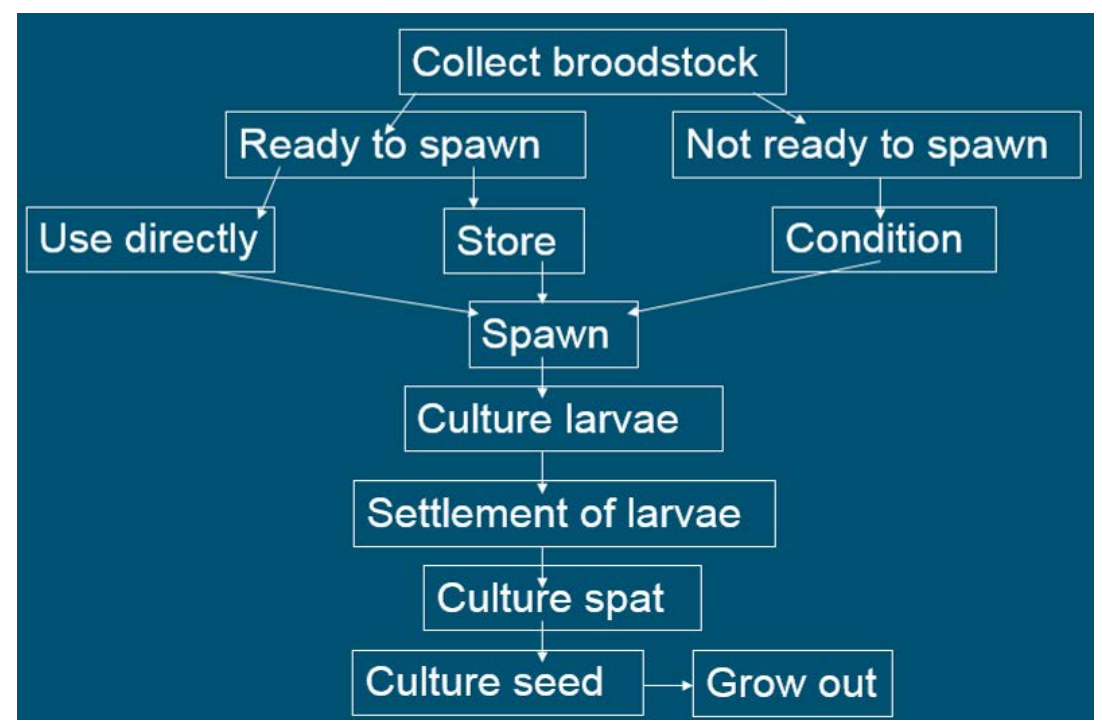

Fig. 1. Summary of hatchery process.

The hatchery process is summarised in Figure 1. The first step is to collect the parents (broodstock) from natural or cultured populations. These oysters can either be ready to spawn, or not ready to spawn. When they are ready to spawn, the oysters can be used directly. Alternatively, they can be 
stored at low temperatures where they can be kept in spawning condition up to a few months. When they are not ready to spawn conditioning is needed which involves a gradual temperature increase while providing food over a period of 4 to 6 weeks. After the conditioning period, eggs and sperm can be stripped from the oysters. This involves opening, and thus sacrificing, the oyster. Pacific oysters are either male or female and this can only be distinguished by examining the reproductive glands (gonads). Bivalves commonly have a very high fecundity and a few adult individuals can generate extremely numerous offspring, although reproductive success is highly variable between parental individuals (Boudry et al., 2002). Bivalves are induced to spawn in a controlled environment and gametes are mixed to perform fertilisation. Development to larvae occurs within $48 \mathrm{~h}$. During this phase the larvae are reared in static or flow-through systems and fed live microalgae. Generally, the hatchery cultures these microalgae on site. For Pacific oysters the larval phase lasts around 2 weeks (Figure 2). After this period, they undergo metamorphosis by settling into a substrate. Spat rearing is carried out in a nursery where the oysters are kept onsieves with running seawater (Figure 3 ). The small oysters (spat) are usually reared indoors and fed microalgae that are cultured indoors (Figure 4). Larger oysters (seed) are reared outdoors with algae that are cultured in open ponds (Figure 5). The final product of a hatchery is seed. Different sizes of seed are produced. This is indicated by the size of the mesh that retains the seed, e.g. T8 is seed that stays on a 8-mm sieve. The larger the seed size, the higher the price. The process from broodstock conditioning to T8 seed takes around 5-6 months. The seed is used for grow out to commercial size oysters in the field.
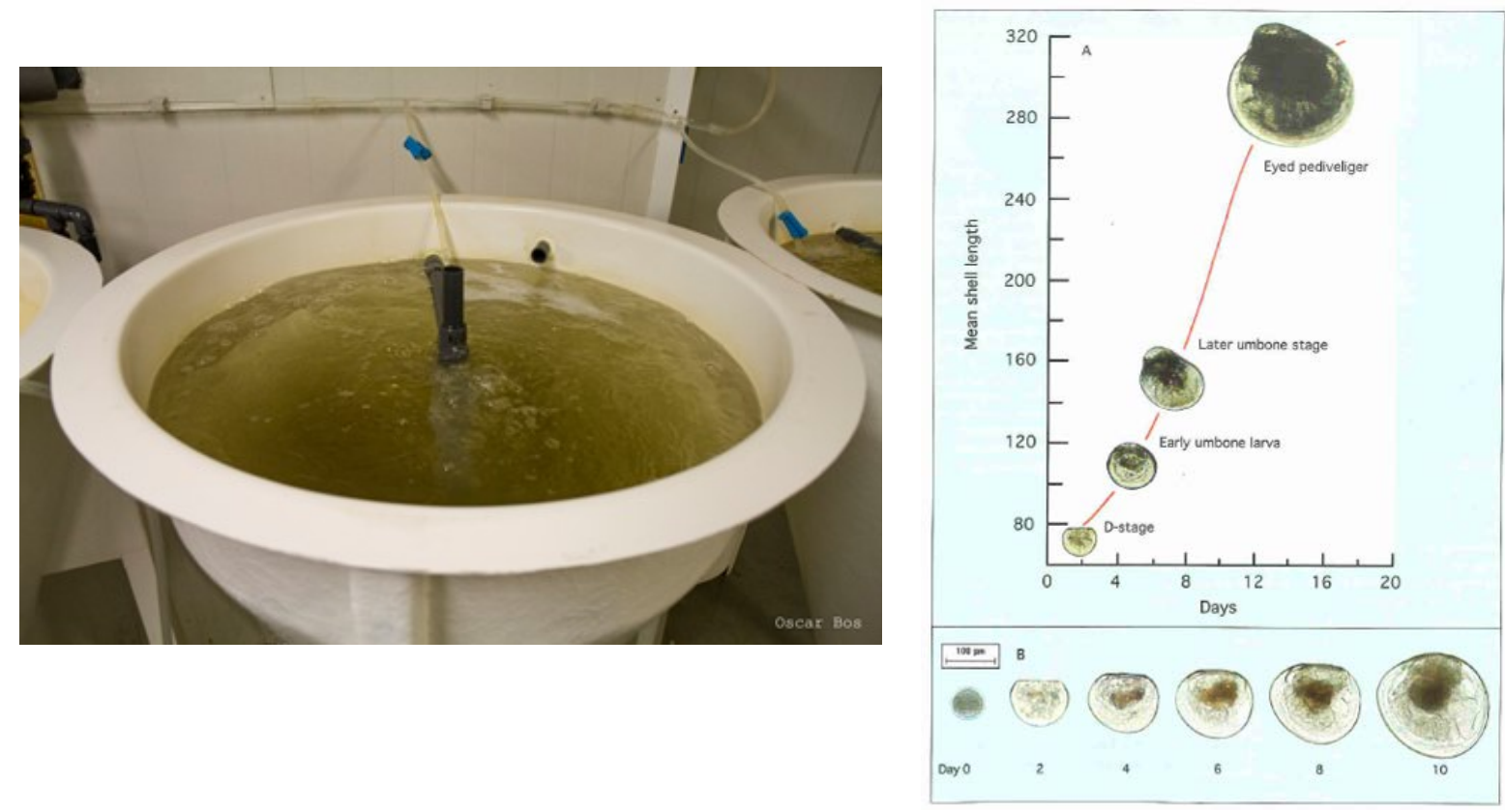

Fig. 2. Larval rearing tank at Dutch hatchery (left, picture Oscar Bos) and growth and development of Pacific oyster larvae (from (Helm et al., 2004)). 

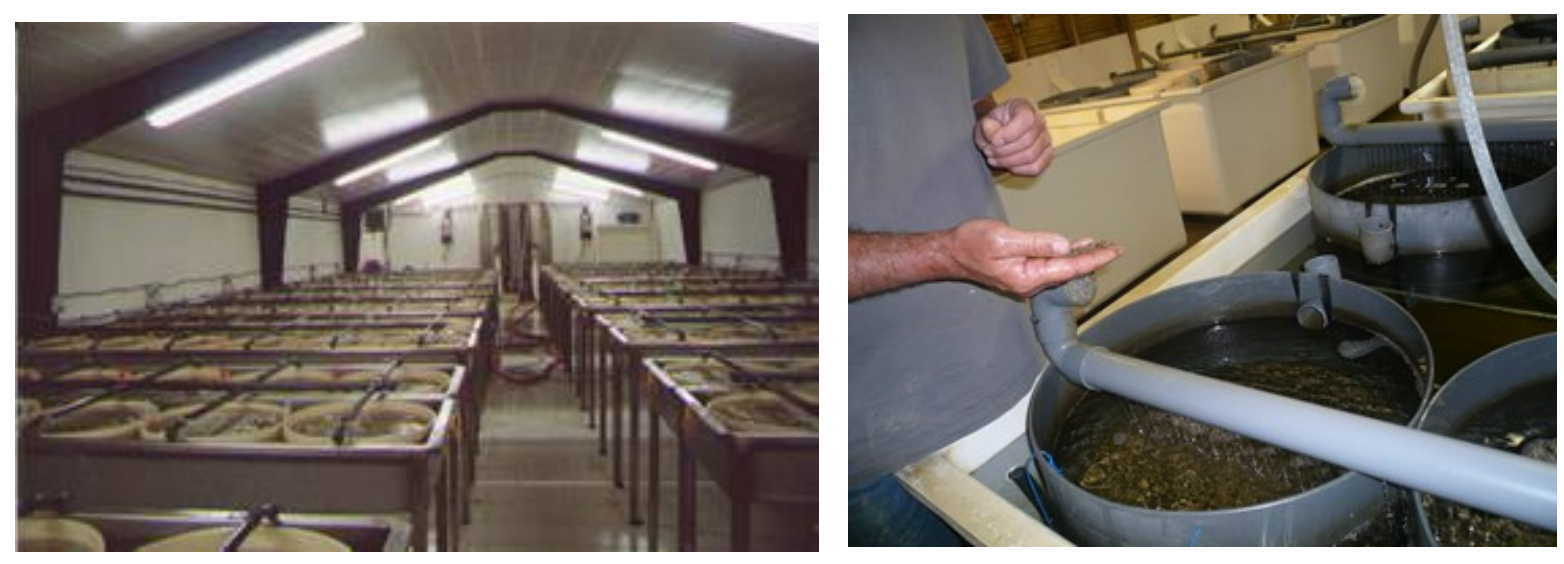

Fig. 3. Indoor nurseries in French hatcheries (pictures Pauline Kamermans).

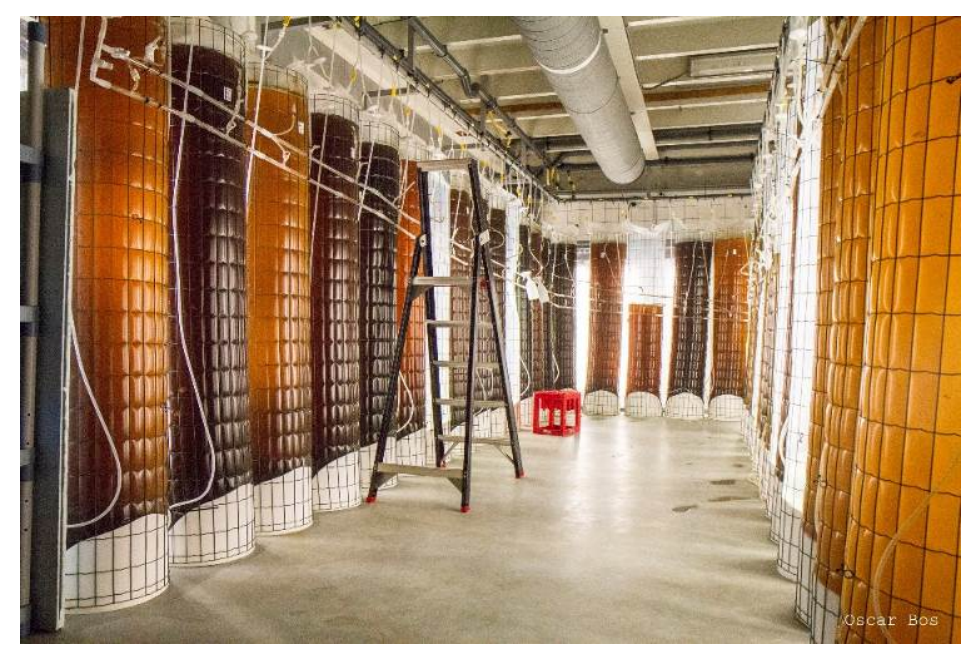

Fig. 4. Algae culture in Dutch hatchery (picture Oscar Bos).

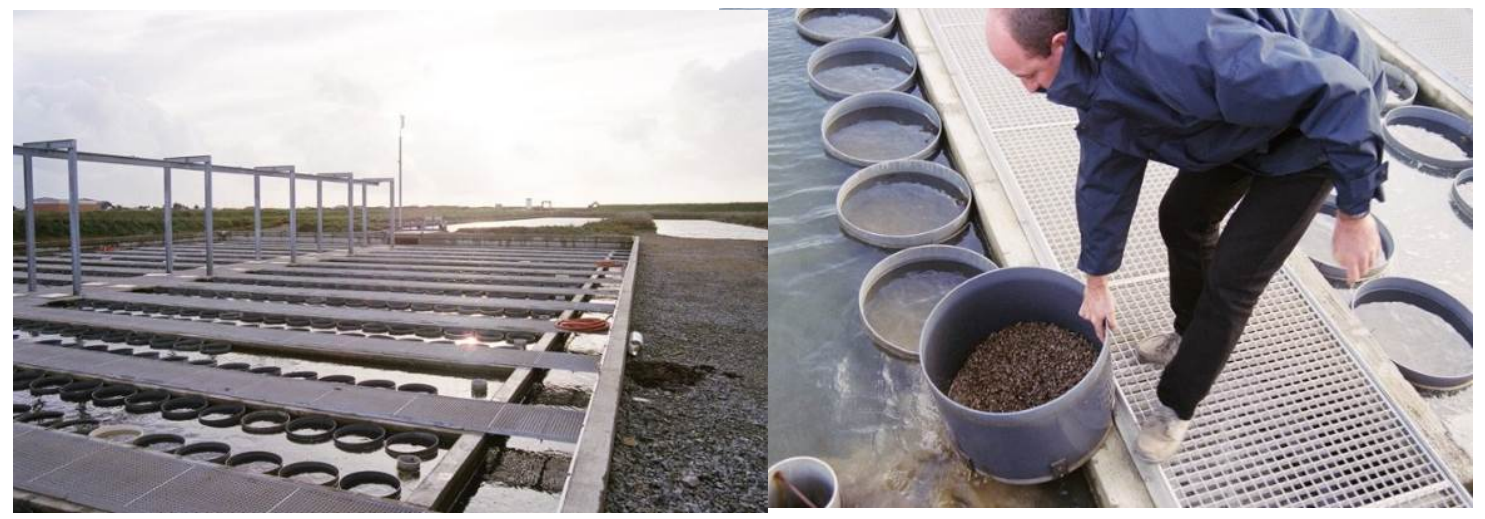

Fig. 5. Outdoor nursey with algal pond in background (left) and close up of sieve with oyster seed (right) in the Vendée area in France (pictures Pauline Kamermans).

Hatcheries and nurseries supply of Pacific oyster seed is increasing every year as a complement of wild seed supply. In Europe, 16 hatcheries in 4 countries produce Pacific oysters (Table 2). However, there is no Pacific oyster hatchery present in Germany. For the oyster farm on Sylt there are three options involving hatchery production for resource provisioning. These are: (1) Setting up a hatchery on Sylt, (2) Acquiring oyster seed from an existing hatchery abroad produced with broodstock from Sylt and (3) Acquiring oyster seed from an existing hatchery abroad produced with broodstock of that 
hatchery. In this study we describe the three options and determine the risks involved. In the follow up study a full technical description of the methods, techniques and infrastructure needed will be provided for the most promising options.

\section{Oyster seed from a hatchery on Sylt}

The setup of a hatchery and nursery on Sylt is an option to provide risk-free oyster seed for grow out near Sylt. Local broodstock can be used. Rearing up to seed size in a local nursery excludes import of non-native species. Building and running a hatchery and nursery is expensive. Specific infrastructure and skilled personnel are needed. This can be done single-handedly or in cooperation. The recent German initiative to restore European flat oysters in the North Sea (Project RESTORE https://www.awi.de/en/science/biosciences/shelf-sea-system-ecology/main-research-focus/europeanoyster.html) includes looking into the feasibility of creating a hatchery for flat oysters as part of a restoration program. This can provide opportunities for cooperation and sharing of expertise and costs.

Table 2. Pacific oyster hatcheries in Europe.

\begin{tabular}{|l|l|l|l|}
\hline Country & Name & Nursery & Contact \\
\hline France & Satmar & Yes & http://www.satmar.fr \\
\hline France & $\begin{array}{l}\text { France Naissain \& Vendée } \\
\text { Naissain }\end{array}$ & Yes & http://www.francenaissain.com \\
\hline France & Grainocéan & Yes & +33546292929 \\
\hline France & SODABO & Yes & \\
\hline France & & No & Benance 9 Chemin De La Pointe, 56370 \\
& Ecloserie des Lilas & Sarzeau, France \\
\hline France & Ecloserie de Kerné & No & LE TINDIO 56640 ARZON \\
\hline France & Vendée Ecloserie & No & +336 46 42 05 79 \\
\hline France & Ecloserie Labadie & Yes & Polder Sud, 85230 Bouin \\
\hline France & Novostréa Bretagne & Yes & https://www.novostrea.net \\
\hline France & Marinove & Yes & http://www.marinove.fr \\
\hline United Kingdom & Seasalter (Walney) Limited & Yes & https://morecambebayoysters.co.uk \\
\hline United Kingdom & Seasalter Shellfish Whistable & Yes & http://www.oysterhatchery.co.uk/ \\
\hline United Kingdom & Guernsey Sea Farms & Yes & http://www.guernseyseafarms.com/ \\
\hline Ireland & Cartron Point Shellfish Ltd & Yes & +353 (0)65 707 8189 \\
\hline Ireland & Tralee Bay & Yes & http://traleebayhatchery.com/ \\
\hline Ireland & Boed Mor & Yes & \\
\hline Netherlands & Roem van Yerseke & Yes & http://roemhatchery.nl/en/ \\
\hline
\end{tabular}

\section{Oyster seed from existing hatchery abroad produced with broodstock from Sylt}

Investment costs can be reduced by making use of one of the existing commercial hatcheries in Europe (Table 2). They may be willing to spawn oyster broodstock from Sylt for breeding oyster spat. Using broodstock from Sylt will ensure the oysters are adapted to the local environmental conditions. This can then be reared to seed in an outdoor nursery on Sylt. In this way import of non-native species is excluded and investments are only needed for the nursery phase. However, although costs may be reduced they will not be inexistent. Those hatcheries will also charge for the work hours, the materials etc. and probably they will also need to build a "quarantine" area to decrease the risk of introducing the non-native species into their area.

An alternative is to culture the oysters to seed at the out-door nursery of the existing hatchery.. However, rearing spat to seed in the foreign out-door nursery provides a risk of introduction of nonnative species and diseases. 


\section{Oyster seed from existing hatchery abroad produced with their broodstock}

Investment costs can be further reduced by making use of one of the existing commercial hatcheries in Europe. They can produce oyster spat for further rearing in a nursery on Sylt. Costs involved are purchase of small spat and a small investment in nursery infrastructure and skilled personnel. I mport of non-native species is excluded. And finally, the least expensive option is purchase of oyster seed from a hatchery abroad. Only costs of purchase of seed are involved. However, rearing spat to seed in the foreign out-door nursery provides a risk of introduction of non-native species and diseases, such as the oyster herpes virus (Renault et al., 1994). 


\section{Use of wild oysters as a resource}

Oysters can be harvested from wild populations by fishery or handpicking. Collected wild oysters are generally directly put on the market after sorting. In the Oosterschelde, handpicked oysters (of about 40-50 g) were put in meshed bags and placed on tables to improve meat content and shell shape. No evidence was found that meat content or shell shape did improve after the transfer of oysters to tables (Capelle et al., submitted), or after transfer of oysters from tables to bottom (Capelle et al., 2016). However, oysters that remained on tables developed a more cup shell shaped than oysters from tables that were relayed on the bottom (Capelle et al., 2016).

The advantage of using handpicked (half-grown) oysters from the same area is the absence of rearing costs. Further half-grown oysters survival rate is higher compared to oyster spat survival.

Disadvantages are the high amount of effort needed to collect oysters, that often grow together into clumps and the shape of the oysters is often not as desired by the industry. As those oysters can also be sold directly, re-stocking in off-bottom systems needs to give the oysters added value. However, experiences from the Oosterschelde (see above) learned that oysters originated from wild beds did not change their shape, when placed off-bottom. It is in particular the shape that makes oyster from offbottom culture more valuable than bottom grown oysters (Brake et al., 2003). In fact, at the culture site in the Oosterschelde they switched to oysters from hatchery or spat collectors as resource. 


\section{$4 \quad$ Use of spat collectors}

Oyster larvae need hard substrate to settle on. When hard substrate is provided at the time when oyster larvae are settling, oyster spat can be collected. In Lake Grevelingen in the Netherlands several experiments were carried out to test different spat collectors for oysters (Kamermans et al., 2004 ; van den Brink et al., 2013). Chinese hat collectors and mussel shells yielded the best results. Furthermore, results show that there are more species that like to settle on hard substrate and fouling can be a major problem especially in submerged collectors. Therefore, best practice is to present the collector around the peak in oyster larvae. Larvae of Pacific oysters have a free living phase of approximately three weeks under natural circumstances, which is about one week longer than in a hatchery (Troost, 2009). A yearly larval monitoring program (to capture yearly fluctuations) is advised to optimize placement of the collectors. And prior to considering the option of spat collection it should be investigated whether larvae are present in sufficient numbers in the culture area to use spat collectors.

In the Netherlands, experience with Chinese hat collectors showed very good results at culture sites. Oysters are also easily removed from the collectors by popping them inside out in with a specialised machine. Another advantage of using spat collectors is that the spat originates from the same region.

Spat from collectors can be harvested anytime, depending on the use of the spat. When growth conditions are good, spat collected in summer can be harvested for bag culture at the end of the same year, such as in Japan (Arakawa, 1990). In the Oosterschelde estuary in the Netherlands, spat collected in summer is harvested the following Spring. When the spat is too small to be placed directly in the bags they can be transferred to a nursery prior to grow-out.
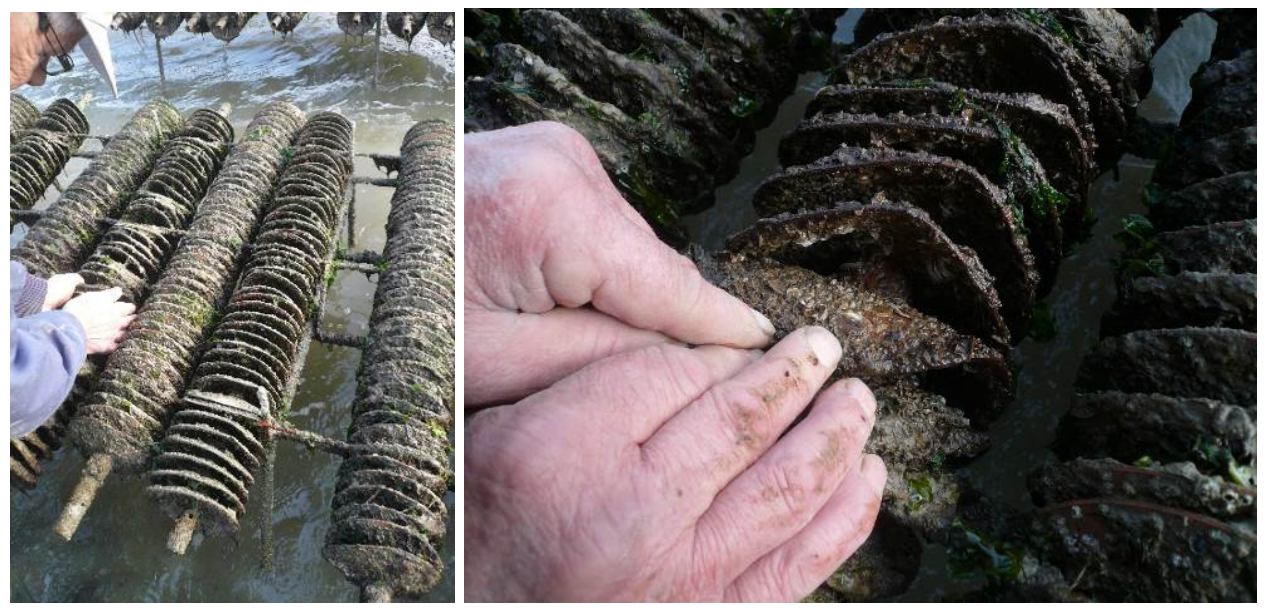

Fig 6 Spat collecors (Chinese hats) at oyster culture site in the Oosterschelde, overview (left) and detail showing the oyster spat on the collector (right) 


\section{Use of a technically safe quarantine for import oysters}

Special quarantine systems are kept in the Netherlands to store living bivalves imported from areas without nature conservation permits for transplants

(http://www.pvis.nl/beeindigde_activiteiten/quarantainevoorzieningen/). The associated flora, fauna and non-living material needs to be destroyed. Quarantine systems are closed systems, or systems where water is purified before it is drained. A quarantine period of a few months in combination with a monitoring program on the effluent water and shellfish reduces the risk of species introduction (Norton et al., 1993). Other measures that were successfully applied for oysters killing fouling organisms and (macro) algae are heat treatments and submersion in saturated brine (Verlaque et al., 2007).

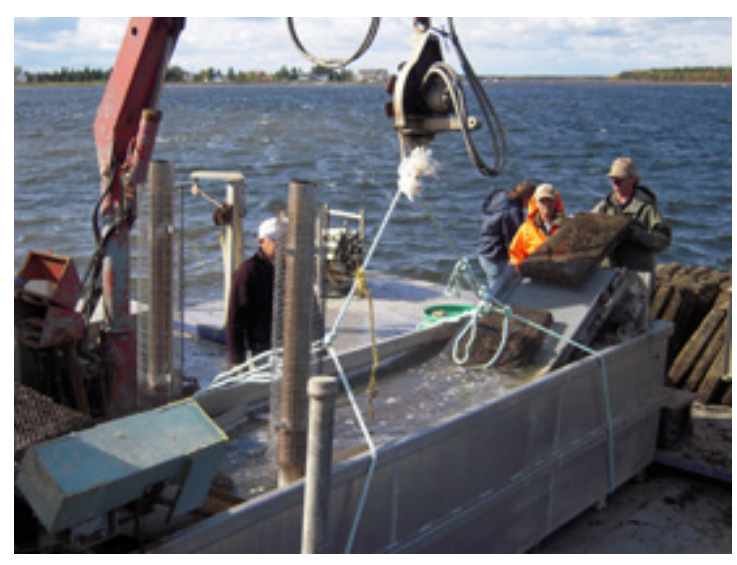

Figure 7 Hot water baths to remove fouling from oyster bags (http://www. dfompo.gc.ca/aquaculture/rp-pr/acrdp-pcrda/projects-projets/MG-08-01-003-eng.html)

However, although risks can be minimized, none of the quarantine or fouling destruction methods are $100 \%$ effective. Basically because treatments cannot be too severe in order not to kill the oysters and also because not all organisms live on the shell, some live in or within the shell. In general, if introduction of non-native species needs to be prevented, hatchery production either on Sylt or abroad is the best solution (Wolff \& Reise, 2002). 


\section{Conclusions and recommendations}

Options for resource provisioning for an oyster farm in Sylt were inventoried. Important aspects considered were: risks for the environment, costs, reliability and quality of the resource. Aspects are summarized in Table 3 for the different methods under study. Colours are used to indicate the relative score, with red representing the high end of risks and costs and the low end of reliability and quality , orange medium scores and green representing the low end of risks and costs and the high end of reliability and quality.

Hatchery (1-4). The lowest risk of import of non-native species is present in those options where a nursery is located on Sylt. Risk of introduction of diseases via foreign reared spat is uncertain and should be evaluated. These are Options 1, 2 and 4. Option 2 and 4 are more cost effective. In these cases, only nursery facilities are needed. However, when a local hatchery (Option 1) can be combined with other initiatives the costs can be substantially reduced.

Wild oysters as resource (5). Wild oysters as a resource has the advantage that oysters originate from the region and costs are limited to effort for collecting. The desired number of oysters should be available in the vicinity, it must be permitted and quality should improve in off-bottom culture, otherwise the oysters can be put on the marked directly. However, quality of hand-picked oysters (shape) is lower than other resources.

Spat collectors (6). Spat collectors as part of the culture system have the advantage that the oyster seed originates from the area. It is a relative cheap method, it only requires material and effort harvesting them. Harvest is not restricted to a certain period and can take place whenever it is needed or when effort is available. Experience learns that shape of the shells is a little bit more irregular than seed from hatchery.

Technically safe quarantine for import oysters (7). No quarantine is $100 \%$ successful, although some methods have shown good results in reducing the number of alien species.

\section{Recommendations}

Based on the inventory, summarized in Table 3, we propose to carry out a technical analysis for option 1 (Hatchery on Sylt), option $2+4$ (Existing hatchery with nursery) and option 7 (Spat collectors). The option of having oysters imported from a nursery from abroad (option $3+5$ ), is still associated with the risk of the introduction exotic species and may require a quarantine treatment (option 8). However, option 8 possesses the largest environmental threat and will require further research including an extensive risk assessment before considering this option. Use of wild oysters as resource can be a cheap option, but given the low quality and low level of control is also disregarded.

Thus, a full technical description of the methods, techniques and infrastructure needed for option 1 , $2+4$ and 7 (Table 3) will be provided in the second part of the feasibility study and will be reported separately. Estimating risks for introduction of diseases, reduced genetic diversity or carrying capacity of the area will be included in the analysis for these options. These will depend on the scale of the operation. 



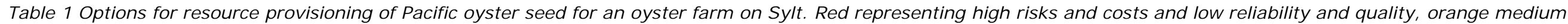
scores and green representing low risks and costs and high reliability and quality.

\begin{tabular}{|c|c|c|c|c|c|c|c|}
\hline Option & $\begin{array}{l}\text { Location of } \\
\text { hatchery }\end{array}$ & $\begin{array}{l}\text { Origin of } \\
\text { brood- } \\
\text { stock }\end{array}$ & $\begin{array}{l}\text { Location } \\
\text { of out- } \\
\text { door } \\
\text { nursery }\end{array}$ & Risks for environment & Preliminary economic assessment & Reliability* & Quality resource \\
\hline $\begin{array}{l}\mathbf{1} \text { Hatchery on } \\
\text { Sylt }\end{array}$ & Sylt & Sylt & Sylt & $\begin{array}{l}\text { None for invasive } \\
\text { species }\end{array}$ & $\begin{array}{l}\text { Large investment needed in hatchery } \\
\text { infrastructure and skilled personnel }\end{array}$ & high & High \\
\hline $\begin{array}{l}2 \text { Existing } \\
\text { hatchery }\end{array}$ & Abroad & Sylt & Sylt & $\begin{array}{l}\text { None for invasive } \\
\text { species, risk of } \\
\text { introducing diseases }\end{array}$ & $\begin{array}{l}\text { Costs of transfer of broodstock, rearing costs } \\
\text { and purchase of small seed } \\
\text { Small investment needed in nursery } \\
\text { infrastructure and skilled personnel }\end{array}$ & high & High \\
\hline $\begin{array}{l}3 \\
\text { Existing } \\
\text { hatchery }\end{array}$ & Abroad & Sylt & $\begin{array}{l}\text { In country } \\
\text { of hatchery }\end{array}$ & $\begin{array}{l}\text { Invasive species can } \\
\text { attach in outdoor } \\
\text { nursery }\end{array}$ & $\begin{array}{l}\text { Costs of transfer of broodstock, rearing costs } \\
\text { and purchase of seed }\end{array}$ & high & High \\
\hline \begin{tabular}{|l} 
\\
Existing \\
hatchery \\
\end{tabular} & Abroad & $\begin{array}{l}\text { From } \\
\text { hatchery }\end{array}$ & Sylt & $\begin{array}{l}\text { None for invasive } \\
\text { species, risk of } \\
\text { introducing diseases }\end{array}$ & $\begin{array}{l}\text { Costs of purchase of small seed } \\
\text { Small investment in nursery infrastructure and } \\
\text { skilled personnel }\end{array}$ & high & High \\
\hline $\begin{array}{l} \\
\text { Existing } \\
\text { hatchery } \\
\end{array}$ & Abroad & $\begin{array}{l}\text { From } \\
\text { hatchery }\end{array}$ & $\begin{array}{l}\text { In country } \\
\text { of hatchery }\end{array}$ & $\begin{array}{l}\text { Invasive species can } \\
\text { attach in outdoor } \\
\text { nursery }\end{array}$ & Costs of purchase of seed & high & High \\
\hline \begin{tabular}{|l|l}
6 \\
Wild oysters
\end{tabular} & \multicolumn{3}{|l|}{ Origin: Sylt } & $\begin{array}{l}\text { None for invasive } \\
\text { species }\end{array}$ & Effort depending on availability & $\begin{array}{l}\text { Dependent on natural } \\
\text { dynamics over a longer period }\end{array}$ & Low \\
\hline $\begin{array}{l}7 \\
\text { Spat collectors }\end{array}$ & \multicolumn{3}{|l|}{ Origin: Sylt } & $\begin{array}{l}\text { None for invasive } \\
\text { species }\end{array}$ & $\begin{array}{l}\text { Small investment in collectors, harvest and } \\
\text { personnel }\end{array}$ & $\begin{array}{l}\text { Dependent on natural } \\
\text { dynamics over a short period }\end{array}$ & Medium-High \\
\hline $\begin{array}{l}8 \\
\text { Import of } \\
\text { resource }\end{array}$ & \multicolumn{3}{|c|}{ Origin: abroad } & $\begin{array}{l}\text { High for invasive } \\
\text { species }\end{array}$ & $\begin{array}{l}\text { Cost of resource, transport and quarantine } \\
\text { measures }\end{array}$ & high & High \\
\hline
\end{tabular}

* Regulations, permits and policies were not considered in the analysis. 


\section{Quality Assurance}

Wageningen Marine Research utilises an ISO 9001:2008 certified quality management system (certificate number: 187378-2015-AQ-NLD-RvA). This certificate is valid until 15 September 2018. The organisation has been certified since 27 February 2001. The certification was issued by DNV Certification B.V.

Furthermore, the chemical laboratory at IJ muiden has NEN-EN-ISO/IEC 17025:2005 accreditation for test laboratories with number L097. This accreditation is valid until $1^{\text {th }}$ of April 2021 and was first issued on 27 March 1997. Accreditation was granted by the Council for Accreditation. The chemical laboratory at IJ muiden has thus demonstrated its ability to provide valid results according a technically competent manner and to work according to the ISO 17025 standard. The scope (L097) of de accredited analytical methods can be found at the website of the Council for Accreditation (www.rva.nl).

On the basis of this accreditation, the quality characteristic $\mathrm{Q}$ is awarded to the results of those components which are incorporated in the scope, provided they comply with all quality requirements. The quality characteristic $\mathrm{Q}$ is stated in the tables with the results. If, the quality characteristic $\mathrm{Q}$ is not mentioned, the reason why is explained.

The quality of the test methods is ensured in various ways. The accuracy of the analysis is regularly assessed by participation in inter-laboratory performance studies including those organized by QUASIMEME. If no inter-laboratory study is available, a second-level control is performed. In addition, a first-level control is performed for each series of measurements.

In addition to the line controls the following general quality controls are carried out:

- Blank research.

- Recovery.

- Internal standard

- Injection standard.

- Sensitivity.

The above controls are described in Wageningen Marine Research working instruction ISW 2.10.2.105. If desired, information regarding the performance characteristics of the analytical methods is available at the chemical laboratory at IJ muiden.

If the quality cannot be guaranteed, appropriate measures are taken. 


\section{References}

Arakawa KY (1990) Natural spat collecting in the Pacific oyster Crassostrea gigas (Thunberg). Marine \& Freshwater Behaviour \& Phy, 17, 95-128.

Brake J, Evans F, Langdon C (2003) Is beauty in the eye of the beholder? Development of a simple method to describe desirable shell shape for the Pacific oyster industry. Journal of Shellfish Research, 22, 767-772.

Capelle J, Hartog E, Creemers J, Heringa J, Kamermans P (submitted) Effects of stocking density and emersion time on the performance of oysters (Mallagana gigas) in intertidal off-bottom culture

Capelle JJ, Payne M, Shields E, Heringa J (2016) Resultaten monitoringsprogramma off-bottom oesterkweek Oosterschelde. Delta Acamdemy, HZ University of Applied Sciences, Vlissingen.

Helm MM, Bourne N, Lovatelli A (2004) Hatchery culture of bivalves. A practical manual. FAO Fish. Tech. Pap., 471, 176.

Kamermans P, Brummelhuis E, Poelman J, van Gool A, Troost K (2004) Onderzoek naar verbetering broedvangst oesters. RIVO.

Norton J, Braley R, Anderson I (1993) A quarantine protocol to prevent the spread of parasitic diseases of giant clams (Tridacnidae) via translocation. In: ACIAR PROCEEDINGS. Australian Centre for International Agricultural Research, pp. 24-24.

Renault T, Le Deuff R-M, Cochennec N, Maffart P (1994) Herpesviruses associated with mortalities among Pacific oyster, Crassostrea gigas, in France-Comparative study. Revue de Médecine Vétérinaire, $145,735-742$.

Troost K (2009) Pacific oysters in Dutch estuaries. Causes of success and consequences for native bivalves., Department of Marine Biology, the Netherlands. Univeristy of Groningen, the Netherlands.

van den Brink A, Fomsgaard C, Nédélec M, Hussenot M, Kamermans P (2013) OYSTERECOVER: Testing the efficiency of different Spat Collectors. IMARES.

Verlaque M, Boudouresque C-F, Mineur F (2007) Oyster transfers as a vector for marine species introductions: a realistic approach based on the macrophytes. In: CIESM Workshop Monographs, Monaco, pp. 39-48.

Wolff WJ, Reise K (2002) Oyster imports as a vector for the introduction of alien species into northern and western European coastal waters. In: Invasive aquatic species of Europe. Distribution, impacts and management. Springer, pp. 193-205. 


\section{J ustification}

Report C113.17

Project Number: 4313100076

The scientific quality of this report has been peer reviewed by a colleague scientist and a member of the Management Team of Wageningen Marine Research

Approved: $\quad$ Ainhoa Blanco, Msc

Shellfish researcher

Signature:

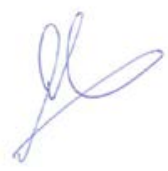

Date: $\quad 21$ dec 2017

Approved: Drs.J.Asjes

Signature:

Date:

21 dec. 2017 
Wageningen Marine Research

T +31 (0)317480900

E: marine-research@wur.nl

www.wur.eu/marine-research

Visitors' address

- Ankerpark 271781 AG Den Helder

- Korringaweg 7, 4401 NT Yerseke

- Haringkade 1, 1976 CP IJ muiden
Wageningen Marine Research is the Netherlands research institute established to provide the scientific support that is essential for developing policies and innovation in respect of the marine environment, fishery activities, aquaculture and the maritime sector.

\section{Wageningen University \& Research:}

is specialised in the domain of healthy food and living environment.

\section{The Wageningen Marine Research vision}

'To explore the potential of marine nature to improve the quality of life'

\section{The Wageningen Marine Research mission}

- To conduct research with the aim of acquiring knowledge and offering advice on the sustainable management and use of marine and coastal areas.

- Wageningen Marine Research is an independent, leading scientific research institute

Wageningen Marine Research is part of the international knowledge organisation Wageningen UR (University \& Research centre). Within Wageningen UR, nine specialised research institutes of the Stichting Wageningen Research Foundation have joined forces with Wageningen University to help answer the most important questions in the domain of healthy food and living environment. 